\title{
The Impact of Formal Planning on the \\ Financial Performance of \\ REAL Estate FIRMS ${ }^{1}$
}

\author{
D. Robley Wood, Jr. \\ Russell A. Johnston \\ Guy J. DeGenaro \\ School of Business \\ Virginia Commonwealth University \\ Richmond, Virginia
}

The body of academic literature on the relationship between formal planning efforts and financial performance contains mixed results (see [2], [11]). The effectiveness of formal planning has also been debated in the popular business literature. Nevertheless, the idea that a structured format for processing information and evaluating alternatives should result in superior decisions is both logical and intuitively appealing.

This research investigates the relationship between the formal planning efforts and financial performance for a sample of real estate firms located in the State of Virginia, U.S.A. It was hypothesized that Virginia real estate firms that were more formal in their planning would financially outperform those that were less formal. The Guttman scaling method was used to develop a formal planning scale for the real estate firms. The group of real estate firms which scored high on the formal planning scale were compared with those that scored low.

\section{Literature Review}

During the past twenty years various researchers have conducted empirical studies into the relationship between formal planning efforts and organizational performance (for reviews, see [2], [11]). Typically, the researchers have divided their sample into groups such as "planners vs. non-planners" (e.g., [6], [12]) and then compared the financial performance of the two groups over a specific period of time. The results of these studies have not been consistent ([2], [11]). Kudla [5] stated that one reason for the inconsistent results could be the method that was used to divide the sample into planners and non-planners. To reduce the chance of improper classification, Wood and LaForge ([14], [15])

\footnotetext{
${ }^{1}$ This research was made possible by funding from the Virginia Real Estate Research Center.
}

Journal of Business Strategies, Volume 5, Number 1 (Spring 1988) 
suggested that the Guttman scaling method be used to categorize organizations when conducting empirical research on the relationship between planning and performance. Venkatraman, Ramanujam and Camillus [13] studied data from 202 strategic planning units and concluded that the use of Guttman scales in planning studies is feasible and desirable. Therefore, in this study a Guttman planning scale was developed and used to classify the real estate firms into those with more formal planning and ones with less formal planning.

\section{Guttman Scaling}

Guttman scaling is a method of determining whether a series of questions are related to each other in such a way that one who replies affirmatively to the second question should also reply affirmatively to the first question; one who replies affirmatively to the third question should reply affirmatively to questions one and two, and so forth. This means that all real estate firms for which any particular question was answered affirmatively should have a higher score on the total scale than those firms for which that question was not answered affirmatively. The score for each firm is computed by counting the number of questions that were answered affirmatively.

With cumulative scaling, a given score for a series of questions always has the same meaning. That is, respondents in every real estate firm that have a total score of two will have replied affirmatively to the first two questions and not affirmatively to the remaining questions. Since a perfect cumulative scale is very difficult to develop, 10 percent discrepancies are considered acceptable. A discrepancy would result if a firm's representative responded affirmatively to questions one and three while not responding affirmatively to question two.

The premise of the Guttman method is that if a series of questions on a subject, such as planning, can be developed where the responses deviate only slightly from the ideal scale pattern, then these questions form a scale which is ordinal. In addition, Guttman maintains that if a series of questions are related in such a way that they form a cumulative scale, then the subject being studied involves only a single dimension and therefore the scale is unidimensional. For more information about Guttman scales, please see [4], [7], or [15].

\section{Method}

The research for the present study was initiated in March 1984, when personal, in-depth interviews were held with executives in seven real estate firms, a staff specialist with the Virginia Association of Realtors and the director of the Virginia Real Estate Research Center. The purpose of the interviews was to gain insights into the management practices of the real estate industry so a quick-answer questionnaire could be constructed. The resulting quick-answer questionnaire contained eighteen questions, and covered such topics as legal form of ownership, year firm was established, use of outside consultants, planning practices and financial data for 1982 and 1983 . All or part of eight questions 
were used to collect data on the planning practices of the real estate firms. The questions were designed to collect information on real estate firms which had little formal planning as well as those which were more comprehensive in their planning practices. One six-part question was used to collect information on the financial characteristics of the real estate firms.

The questionnaire was mailed to all Virginia Association of Realtors (VAR) principal broker members that were on the Association's computerized mailing list. Each real estate firm has only one principal broker and 2,050 were on the Association's 1984 mailing list. The mailing of the questionnaire was conducted during July 1984. The mailing packet contained an explanatory cover letter, the questionnaire and a post card. To ensure the confidentiality of the replies, the respondents were asked not to sign the questionnaire. For purposes of providing to the respondents copies of the study, each was asked to sign a post card and mail it separately from the mailing of the completed questionnaire. Of the 305 returned questionnaires, 126 contained all planning and financial data and were used as the sample for this paper.

The low response rate of 305 out of 2,050 may be attributable to several factors. Since specific financial information was solicited, many brokers may have been reluctant to divulge confidential data to the extent requested. Additionally, the questionnaires were mailed bulk-rate. Thus, the number not forwarded to new addresses was lost to the study. It is also not known how many organizatioms were no longer in business when the questionnaires were mailed.

The sample used in this study, 126 real estate firms in Virginia, was tested for representativeness using national data reported by the National Association of Realtors (NAR) in their Profile of Real Estate Firms, 1989 [8]. In terms of activity (brokerage versus non-brokerage), our sample of Virginia firms tends to be comparable to the national distribution record in the NAR study.

The responses to the planning-related questions were arranged in a logical order starting with a total absence of formal planning and going through strategic long-range corporate planning. The responses were checked to see that they formed the proper cumulative pattern necessary for a Guttman scale. It was found that the responses did form the triangular pattern, but more than 10 percent of the responses deviated from a perfect scale. However, through an iterative procedure it was possible to identify a set of nine questions that met the Guttman criteria of less than 10 percent discrepancies. The actual discrepancy rate was 7.84 percent for the scale that is presented in Figure 1. The nine questions that scaled are in the order they appear in the scale from "more of the real estate firms agreed with" to "fewer of the real estate firms agreed with."

For purposes of analysis, it was decided to collapse the responses into two categories: "Less Formal Planners" and "More Formal Planners." Real estate furms placed in the category of Less Formal Planners scored between zero and four on the lower five scale positions (the score of zero being one of the five 
positions). Real estate firms that were placed in the category of More Formal Planners were ones that scored on the upper five scale positions.

Figure 1

The Applied Scale

\begin{tabular}{|c|c|}
\hline $\begin{array}{l}\text { More of the } \\
\text { Real Estate }\end{array}$ & $\begin{array}{l}\text { It is more likely that things just happen than that } \\
\text { the firm plans it that way.* }\end{array}$ \\
\hline \multirow[t]{5}{*}{$\begin{array}{l}\text { Firms Agreed } \\
\text { With }\end{array}$} & $\begin{array}{l}\text { Your firm makes use of written total revenue pro- } \\
\text { jections for one year or less. }\end{array}$ \\
\hline & $\begin{array}{l}\text { Your firm makes use of written goals/objectives for } \\
\text { one year or less. }\end{array}$ \\
\hline & $\begin{array}{l}\text { Most of the firm's plans exist only in the mind of } \\
\text { the top person in the organization." }\end{array}$ \\
\hline & $\begin{array}{l}\text { There is an integrating of the long range strategic } \\
\text { planning and budgeting processes. }\end{array}$ \\
\hline & $\begin{array}{l}\text { Your various planning activities are consolidated } \\
\text { into a written company plan. }\end{array}$ \\
\hline \multirow{3}{*}{$\begin{array}{l}\text { Fewer of the } \\
\text { Real Estate } \\
\text { Firms Agreed } \\
\text { With }\end{array}$} & $\begin{array}{l}\text { Your firm makes use of a written analysis of } \\
\text { the firm's internal strengths and weaknesses; e.g., } \\
\text { staffing, training, financial, and facilities. }\end{array}$ \\
\hline & $\begin{array}{l}\text { Detailed action plans are used to support each ma- } \\
\text { jor strategy. }\end{array}$ \\
\hline & $\begin{array}{l}\text { Your firm makes use of a detailed, written analysis } \\
\text { of its market area. }\end{array}$ \\
\hline
\end{tabular}

\section{Findings}

The performance of the two groups were compared using average dollar changes in both gross income and net income. The averages were computed by individually calculating the dollar increase or decrease for each real estate firm in a group and then simply averaging them together. Table 1 represents the average dollar changes in net income for 1982-1983. Beneath the headings More Formal Planners and Less Formal Planners is indicated the number of real estate firms in the sample group $(n)$, the average dollar increase in the net income for that group over the one year $\bar{x}$ period and the standard deviation of the average dollar changes in net income $(s)$.

The information in Table 1 shows that there were 34 firms in the sample classified as More Formal Planners. The average of this group's dollar changes 
in net income was a positive $\$ 35,200$ with a standard deviation of $\$ 76,000$. There were 92 firms which were classified as Less Formal Planners. The average of the Less Formal Planners' dollar changes in net income was a positive $\$ 24,000$ with a standard deviation of $\$ 37,260$. The difference in the performance of the two groups is also presented in Table 1 . The information in Table 1 shows that the More Formal Planners in the sample had an average dollar increase in net income for $1982-1983$ that was $\$ 11,200$ greater than the average dollar increase for the Less Formal Planners.

Table 1

Differences in Performance (1982-1983)

Average Dollar Change in Net Income

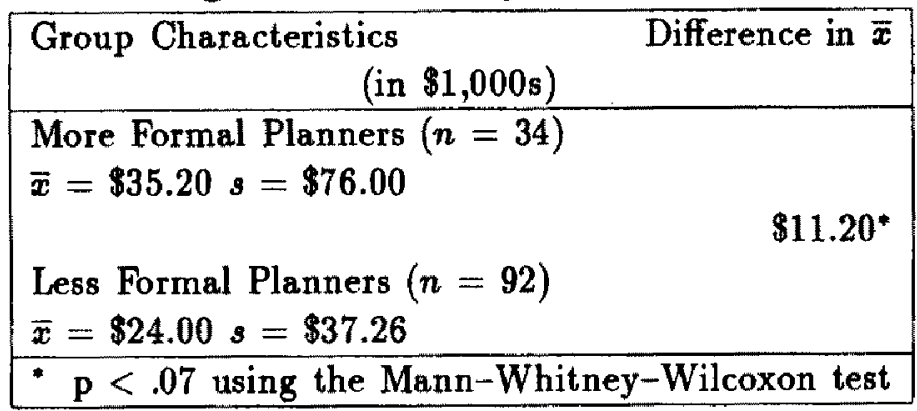

According to the research hypothesis of this study, the More Formal Planners would be expected to outperform the Less Formal Planners. Examination of the data in Table 1 shows that the difference in net income growth was in the hypothesized direction. Statistical significance was determined by use of the Mann-Whitney-Wilcoxon test. The Mann-Whitney-Wilcoxon test was used to test the hypothesis that the population means for any combination of groups of real estate firms is the same, and that the difference recorded in Table 1 indicates that with regard to average dollar growth in net income over the 19821983 period, the 34 More Formal Planners as a group significantly outperformed (at the .07 level) the group of 92 Less Formal Planners.

The information in Table 2 shows a comparison of the More Formal Planners with the Less Formal Planners when the performance measure is average dollar change in gross income.

The More Formal Planners had an average dollar increase in gross income for 1982-1983 of $\$ 218,210$ while the increase for the Less Formal Planners was $\$ 93,950$. The difference in the average dollar increase in gross income between the two groups was $\$ 124,260$ and it was in the hypothesized direction. The results in Table 2 indicate that with respect to average dollar growth in gross income over the 1982-1983 period, the 34 More Formal Planners as a group significantly outperformed (at the .01 level) the group of 92 Less Formal Planners.

The financial performances of the two groups were also compared using average percentage changes in both gross income and net income. By using percentage changes, the problem of "size of firm" affecting the results was taken 
into consideration. However, it is certainly not a perfect measure since it is much easier for smaller firms to show dramatic percentage increases or decreases than for larger firms.

Table 2

Differences in Performance (1982-1983)

Average Dollar Change in Gross Income

\begin{tabular}{|lr|}
\hline \multicolumn{1}{|c|}{$\quad$ (in $\$ 1,000 \mathrm{~s})$} & Difference in $\bar{x}$ \\
\hline \multicolumn{2}{|c|}{ More Formal Planners $(n=34)$} \\
$\bar{x}=\$ 218.21 s=\$ 277.62$ \\
\\
Less Formal Planners $(n=92)$ \\
$\bar{x}=\$ 93.95 s=\$ 346.12$ \\
\hline p $<.01$ using the Mann-Whitney-Wilcoxon test \\
\hline
\end{tabular}

For 1982-83, the average percentage increase in net income for the group of 92 Less Formal Planners was 49.41 percent. During the same period, the average percentage increase in net income for the group of 34 More Formal Planners was 54.75 percent. The difference between the two groups was 5.34 percent and it was in the expected direction. However, because of the amount of variability in the data, the 5.34 percent difference between groups was not statistically significant.

During 1982-83, the average percentage increase in gross income for the group of 93 Less Formal Planners was 33.57 percent. For the same period, the average percentage increase in gross income for the group of 34 More Formal Planners was 39.70 percent. The difference between the two groups was 6.13 percent and it was in the hypothesized direction. However, consistent with the findings for percentage change in net income, the amount of variability in the data for the percentage change in gross income was so large that the 6.13 percent difference between groups was not statistically significant.

Other financial measures were also utilized in this study. Data on dollar investment in the business were collected and determined to be useless in any meaningful analysis. In the real estate business it is possible to rent or lease almost everything one needs to operate. Also, owners do not typically leave large amounts of money in the business. Therefore, investment in the business tends to be a low figure and return on investment ratios are often extremely high.

Information on dollars paid to the owners was also collected for this study. The typical ways the owners receive dollar compensation are salaries, commissions and distributions or dividends. The above categories and percentage increases between 1982-1983 for the Less Formal Planners were as follows: salaries $(31.6 \%)$, commission $(40.0 \%)$ and distributions or dividends $(87.4 \%)$. Similar data for the More Formal Planners is: salaries (53.8\%), commissions (105.6\%), 
and distributions or dividends (294.3\%). The importance of this finding is twofold. First, the More Formal Planners outperformed the Less Formal Planners in all categories of growth in dollar compensation for the owners during the survey period. Second, the differences in growth rates of all forms of compensation to owners were large between groups.

In summary, the financial performance measures were all in the direction of support for the research hypothesis. Specifically, the findings presented below in Table 3 suggest that real estate firms which are more formal in their planning have a competitive advantage over similar furms which make less use of written documents and specific procedures.

Table 3

Average Performance of Firms in Sample (1982-1983)

\begin{tabular}{|lrr|}
\hline \multicolumn{1}{|c}{$\begin{array}{c}\text { Performance } \\
\text { Indicator }\end{array}$} & $\begin{array}{c}\text { Less Formal } \\
\text { Planners }\end{array}$ & $\begin{array}{c}\text { More Formal } \\
\text { Planners }\end{array}$ \\
\hline Number of Firms & 92 & 34 \\
Average Dollar Change in & & \\
$\quad$ Net Income & $\$ 24,000$ & $\$ 35,200$ \\
Gross Income & $\$ 93,950$ & $\$ 218,210$ \\
Average Percentage Increase in & & \\
$\quad$ Net Income & $49.41 \%$ & $54.75 \%$ \\
Gross Income & $33.57 \%$ & $39.70 \%$ \\
Salaries & $31.60 \%$ & $53.80 \%$ \\
Commissions & $40.00 \%$ & $105.60 \%$ \\
Distributions and/or & & \\
Dividends & $87.40 \%$ & $294.30 \%$ \\
\hline
\end{tabular}

\section{Discussion}

In this study a group of real estate firms that engaged in formal planning financially outperformed a group of real estate firms that were less formal in their planning efforts. Previous research of this type produced results that were evenly split for service industry firms. Fulmer and Rue [3] and Robinson and Pearce [9] compared groups of firms in the service industry according to their planning activities and did not find that the firms differed in financial performance. The research results of this study are consistent with the previous finding of Wood and LaForge [15] and Sapp and Seiler [10].

The real estate industry in the United States had a much better year in 1983 than it did in 1982. Because industry performance improved, some of the sample firms had dramatic increases in their sales and income. The dramatic increases experienced by these firms contributed to the large standard deviations for the groups. The differences in size of the individual firms also contributed to the large standard deviations. Small, medium and large real estate firms were in the 
groups of More Formal Planners and Less Formal Planners. The smallest firm in the group of More Formal Planners had only $\$ 40,000$ in gross income for 1983 while the largest reported $\$ 562,000$ in gross income. Large standard deviations are not unusual in this type of research. Examples of other research reporting similar results include Ansoff, Avner, Brandenburg, Porter, and Radosevich [1] and Fulmer and Rue [3].

\section{Conclusion}

The superior financial performance of any firm is attributable to many different factors which are typically referred to as better management practices. The findings of this research suggest that a source of these superior management practices, at least in the area of real estate firms, is comprehensive formal planning by the firm.

\section{References}

1. Ansoff, H. I., J. Avner, R. C. Brandenburg, F. E. Portner, and R. Radosevich. "Does Planning Pay? The Effect of Planning on Success of Acquisitions in American Firms." Long Range Planning, Vol. 3, No. 2 (1970), pp. 2-7.

2. Armstrong, J. S. "The Value of Formal Planning for Strategic Decision: Review of Empirical Research." Strategic Management Journal, Vol. 3 (1982), pp. 197-211.

3. Fulmer, R. M. and Rue, L. W. "The Practice and Profitability of Long Range Planning." Managerial Planning, Vol. 22 (1974), pp. 1-7.

4. Guttman, L. "A Basis for Scaling Qualitative Data." American Sociological Review (1944), pp. 139-150.

5. Kudla, R. J. "The Effects of Strategic Planning on Common Stock Returns." Academy of Management Journal, Vol. 23 (1980), pp. 5-20.

6. Malik, Z. A. and Karger, D. W. "Does Long-Range Planning Improve Company Performance?" Management Review, Vol. 64 (1975), pp. 26-31.

7. Oppenheim, A. N. Questionnaire Design and Attitude Measurement, New York, NY: Basic Books, Inc. (1966), pp. 143-155.

8. Profile of Real Estate Firms, 1989. Washington, DC: National Association of Realtors (1983).

9. Robinson, R. B. and Pearce, J. S. "The Impact of Formalized Strategic Planning on Financial Performance in Small Organizations." Strategic Management Journal, Vol. 29 (1983), pp. 32-36. 
10. Sapp, R. W. and Seiler, R. E. "The Relationship Between Long-Range Planning and Financial Performance of U. S. Commercial Banks." Management Planning, Vol. 29 (1981), pp. 32-36.

11. Shrader, C. B., L. Taylor, and D. R. Dalton. "Strategic Planning and Organizational Performance: A Critical Appraisal." Journal of Management, Vol. 10 (1984), pp. 149-171.

12. Thune, S. S. and House, R. J. "Where Long-Range Planning Pays Off." Business Horizons, Vol. 13 (1970), pp. 81-87.

13. Venkatraman, N., V. Ramanujam, and J. C. Camillus. "Measuring Strategic Planning Characteristics Using Guttman-type Scales: A Generalized Examination." University of Pittsburgh Graduate School of Business Working Paper (1984), pp. 1-29.

14. Wood, D. R. and LaForge, L. "The Impact of Comprehensive Planning on Financial Performance." Academy of Management Journal, Vol. 22 (1979), pp. 516-526.

15. Wood, D. R. and LaForge, L. "Toward the Development of a Planning Scale: An Example from the Banking Industry." Strategic Management Journal, Vol. 27 (1981), pp. 209-216. 